\title{
Production and its fate in two coastal regions of the Irish Sea: the influence of anthropogenic nutrients
}

\author{
R. J. Gowen ${ }^{1, *}$, D. K. Mills ${ }^{2}$, M. Trimmer ${ }^{3, * *}$, D. B. Nedwell ${ }^{3}$ \\ ${ }^{1}$ Aquatic Systems Group, Agricultural and Environmental Science Division, \\ Department of Agriculture for Northern Ireland, Newforge Lane, Belfast BT9 5PX, United Kingdom \\ ${ }^{2}$ Centre for Environment, Fisheries and Aquaculture, Lowestoft Laboratory, Lowestoft, Suffolk NR33 OHT, United Kingdom \\ ${ }^{3}$ School of Biological Sciences, University of Essex, Colchester, Essex CO4 3SQ, United Kingdom
}

\begin{abstract}
Fluvial and sewage loading of N and P to Liverpool Bay (England) elevated winter concentrations of dissolved inorganic $\mathrm{N}(29.2 \mu \mathrm{M})$ and $\mathrm{P}(1.7 \mu \mathrm{M})$ and molar ratios of N:P (17.0) and N:Si (6.0) compared to Irish coastal waters (9.5 $\mathrm{MM}$ N, 0.8 $\mu \mathrm{M}$ P; N:P $12.0 \mathrm{~N}: \mathrm{Si}$ 1.9). At the enriched site in Liverpool Bay, enhanced spring production (up to $3165.8 \mathrm{mg} \mathrm{C} \mathrm{m}^{-2} \mathrm{~d}^{-1}$ ) summer production (471.8 to $971.5 \mathrm{mg} \mathrm{C} \mathrm{m}^{-2} \mathrm{~d}^{-1}$ ) and biomass (4.1 to $13.6 \mathrm{mg}$ chorophyll $\mathrm{m}^{-3}$ ) was dominated by diatoms. Annual production at this site was estimated as $182 \mathrm{~g} \mathrm{C} \mathrm{m}^{-2}$ compared to $97 \mathrm{~g} \mathrm{C} \mathrm{m}^{-2}$ at the Irish coastal station. Enrichment and shifts in nutrient ratios did not favour flagellate growth compared to growth of diatoms in Liverpool Bay. Low amounts of sediment phytopigments (9.2 to $26 \mathrm{mg} \mathrm{m}^{-2}$ ), low concentrations of pore water Si (mean, $9.8 \mu \mathrm{M})$, and a negligible summer benthic efflux of Si $\left(1.0 \mu \mathrm{mol} \mathrm{m}^{-2}\right.$ $\mathrm{h}^{-1}$ ) suggested little phytodetrital input to sediments in Liverpool Bay and that summer diatom production required an allochthonous supply of $\mathrm{Si}$. At the Irish coastal station, coupling between benthic and water-column processes ensured that benthic efflux of Si was sufficient to support the bulk of summer diatom production. Water-column recycling of $\mathrm{N}$ was an order of magnitude greater than sediment recycling of $\mathrm{N}$ at both coastal sites.
\end{abstract}

KEY WORDS: Nutrient enrichment $\cdot$ Primary production $\cdot$ Standing stock $\cdot$ Benthic-pelagic coupling

\section{INTRODUCTION}

Increased inputs of plant nutrients to coastal waters are a common feature in European shelf-seas (Gieskes \& Kraay 1975, van Bennekom et al. 1975, Foster 1984, Tett et al. 1986, Radach et al. 1990). The eventual biological consequences of nutrient enrichment depend on a complex interaction between the level of enrichment (a function of loading, volume of the receiving water and retention in the coastal area) and a suitable light climate for photosynthesis (influenced by solar radiation, attenuation and optical depth). Elevated concentrations of $\mathrm{N}\left(\mathrm{NO}_{3}{ }^{-}+\mathrm{NO}_{2}{ }^{-}\right)$and $\mathrm{P}\left(\mathrm{PO}_{4}{ }^{3-}\right)$ have

\footnotetext{
*E-mail: richard.gowen@dardni.gov.uk

** Present address: Department of Biological Sciences, Queen Mary and Westfield College, University of London, Mile End Road, London E1 4NS, United Kingdom
}

the potential to promote increased algal growth and biomass in the receiving waters (Oviatt et al. 1986, Radach et al. 1990, Schaub \& Gieskes 1991, de Jonge et al. 1996), although for some coastal areas the relationship is weak (Hickel et al. 1993). High levels of $N$ and $\mathrm{P}$ may favour the growth of net (large) species of phytoplankton (Riegman et al. 1993), and it has been suggested that in $\mathrm{N}$ - and $\mathrm{P}$-enriched waters, increased $\mathrm{N}$ to $\mathrm{Si}\left(\mathrm{Si}[\mathrm{OH}]_{4}\right)$ ratios favour the growth of flagellates (Officer \& Ryther 1980, Smayda 1990). Increased microflagellate (including Phaeocyctis spp.) abundance has been linked with nutrient enrichment in Dutch coastal waters (Cadée \& Hedgeman 1986, Cadée 1990), although Riegman et al. (1992) also identified changes in nutrient ratios as a key factor.

Nutrient enrichment of the water column may have indirect effects on benthic processes such as stimulation of sedimentary oxygen uptake, rates of ammonifi- 
cation, and release of $\mathrm{NH}_{4}{ }^{+}$from the sediment surface (Hargrave 1973, Nixon 1981, Kelly \& Nixon 1984, Jensen et al. 1990). In extreme cases the stimulatory effect on benthic oxygen uptake has led to seasonal or long-term hypoxia of bottom water (Rosenberg et al. 1990). At moderate organic loadings, Sloth et al. (1995) measured an increase in nitrification and denitrification, which could mitigate the effects of $\mathrm{N}$ enrichment through loss of N. At higher loadings, however, nitrification and denitrification decreased, leading to a greater efflux of $\mathrm{NH}_{4}{ }^{+}$. There is, therefore, the potential for a positive feed-back loop between production and mineralisation of available N. Van Raaphorst et al. (1992 and references cited therein) suggested a close link between phytoplankton dynamics and benthic activity in shallow, well-mixed water columns.

As part of the UK Joint Nutrient Study (JoNuS II), to investigate the effects of anthropogenic nutrients on the productivity of coastal waters and underlying benthos, nutrient and phytoplankton dynamics, together with sedimentary mineralisation processes were studied in Liverpool Bay, UK (Fig. 1) over an 8 mo period (March to October) in 1997. Additional benthic data are presented from cruises undertaken in May and October 1996. To provide a comparison, a complimentary study was undertaken in Irish coastal waters (Fig. 1) which receives lesser amounts of anthropogenic inputs but is similar hydrographically.

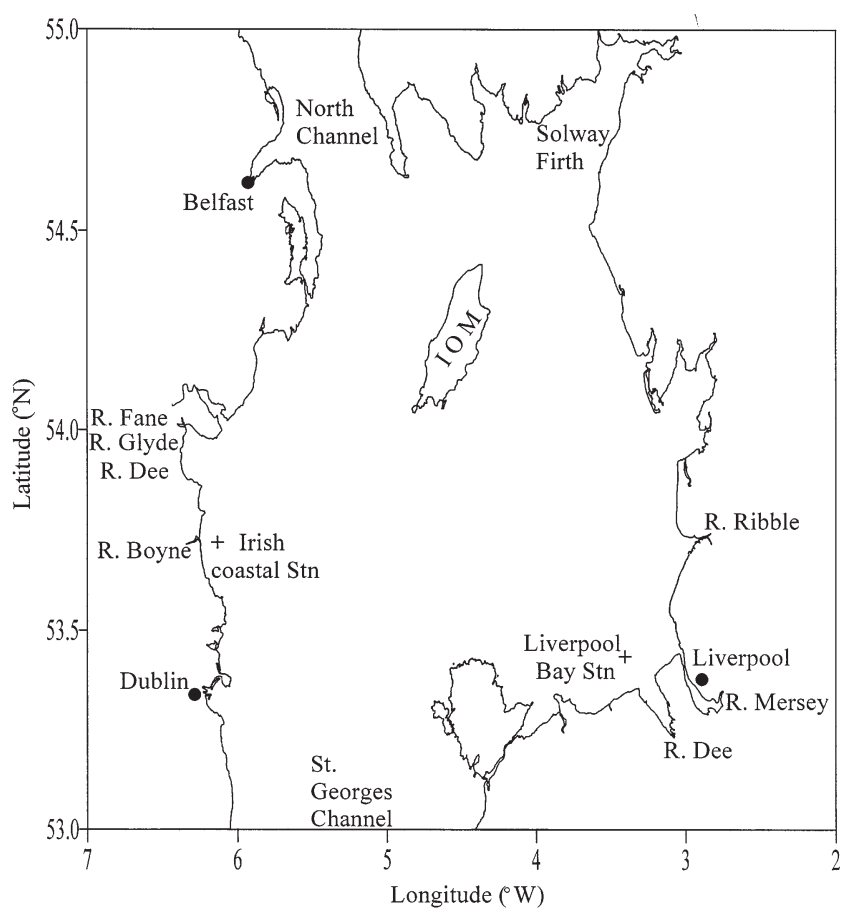

Fig. 1. Map of the Irish Sea showing the locations of the 2 coastal sampling stations (+). IOM: Isle of Man
Fluvial and sewage treatment load data for 1995 and 1996 indicated that, on average, $1.7 \times 10^{9} \mathrm{~mol} \mathrm{~N} \mathrm{yr}^{-1}$ (dissolved inorganic nitrogen, $\mathrm{NO}_{3}{ }^{-}+\mathrm{NO}_{2}{ }^{-}+\mathrm{NH}_{4}{ }^{+}$) together with $100 \times 10^{6} \mathrm{~mol} \mathrm{P} \mathrm{yr}^{-1}$ and $250 \times 10^{6} \mathrm{~mol} \mathrm{Si} \mathrm{yr}^{-1}$ are discharged into Liverpool Bay (UK Department of the Environment, Transport and Regions). Fluvial discharge to the Irish coastal region studied has been estimated as $0.3 \times 10^{9} \mathrm{~mol} \mathrm{~N}$ and $4.5 \times 10^{6} \mathrm{~mol} \mathrm{P} \mathrm{yr}^{-1}$ (Gillooly et al. 1992). There are no direct assessments of silicate input to the region but assuming a maximum

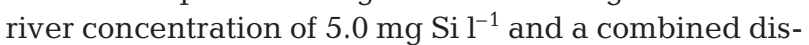
charge from the Fane, Glyde, Dee and Boyne of $56 \mathrm{~m}^{3} \mathrm{~s}^{-1}$ (C. Gibson pers comm.) silicate input to the Irish coastal region can be estimated as $150 \times 10^{6} \mathrm{~mol} \mathrm{Si} \mathrm{yr}^{-1}$.

\section{MATERIALS AND METHODS}

Water-column sampling. Nine cruises were undertaken in the Irish Sea onboard the RVs 'Lough Foyle' and 'Cirolana' between March and October 1997. The study centred on 2 shallow $(20 \mathrm{~m})$ coastal stations (Fig. 1), 1 in Irish coastal waters $\left(53^{\circ} 43^{\prime} \mathrm{N}, 06^{\circ} 09^{\prime} \mathrm{W}\right)$ and the second in Liverpool Bay $\left(53^{\circ} 29^{\prime} \mathrm{N}, 03^{\circ} 25^{\prime} \mathrm{W}\right)$.

Temperature and salinity measurements. During each cruise vertical profiles of temperature and salinity were recorded. Hydro-Bios and FSI (Falmouth Scientific Inc., Cataumet, MA, USA) CTDs mounted on rosette samplers were used onboard 'Lough Foyle' and 'Cirolana', respectively. The CTDs were calibrated for salinity by salinometer measurements on discrete water samples. Temperature calibration of the CTDs was by reversing thermometer.

Irradiance. The diffuse vertical attenuation coefficient $\left(k_{\mathrm{d}}\right)$ of PAR (photosynthetically active radiation) was derived from regression analysis of measurements of downwelling PAR recorded at $1 \mathrm{~m}$ intervals to a depth of $15 \mathrm{~m}$, using a Li-Cor (cosine-corrected) quantum sensor. On occasions when the PAR sensor was not available, depth of the $1 \%$ light level was approximated from measurement of the Secchi depth (Parsons et al. 1984). During RV 'Lough Foyle' cruises, local sea-level radiation was measured by a solarimeter mounted on the ship's mast.

Water-column nutrients. Water samples for estimation of dissolved inorganic nutrients (and chlorophyll) were collected from 4 or 5 depths at each station. During RV 'Lough Foyle' cruises, nutrient samples were filtered (Whatman GF/F) and stored frozen $\left(-20^{\circ} \mathrm{C}\right)$ for later determination of dissolved inorganic $\mathrm{N}\left(\mathrm{NO}_{3}{ }^{-}+\right.$ $\left.\mathrm{NO}_{2}{ }^{-}\right), \mathrm{P}\left(\mathrm{PO}_{4}{ }^{3-}\right)$ and $\mathrm{Si}\left(\mathrm{Si}(\mathrm{OH})_{4}\right)$ using a Bran and Luebbe segmented continuous-flow analyser (TRAACS) employing automated colorimetric methods. Nutrient analysis was carried out onboard RV 'Cirolana' using a continuous flow autoanalyser (Skalar, SA4000, Breda, Netherlands) according to Kirkwood (1996). 
Chlorophyll estimation. Chlorophyll concentrations were determined using the method of Tett (1987). Known volumes of between 0.1 and 0.251 were filtered through GF/F glass fibre filters, and algal pigments extracted in $90 \%$ acetone for $24 \mathrm{~h}$ at $4^{\circ} \mathrm{C}$ in the dark. Measurements of extracted chlorophyll fluorescence were made (before and after acidification with $8 \% \mathrm{HCl}$ to distinguish pheopigments) using a Turner Designs Model 10 filter fluorometer. The fluorometer was calibrated using chlorophyll a (Sigma Chemical Co., Poole, UK). Euphotic-zone (depth at which irradiance was $1 \%$ of surface irradiance) chlorophyll standing stock was determined by interpolation of extracted chlorophyll values.

Phytoplankton species. Near-surface water samples were preserved with acidified Lugol's iodine for determination of phytoplankton species composition and abundance using a sedimentation method described by Tett (1973). Authorities for diatoms are given in Hasle \& Syvertsen (1996) and for dinoflagellates in Dodge (1982) and Steidinger \& Tangen (1996).

Primary production. On 4 RV 'Lough Foyle' cruises, water samples were collected from a depth of $5 \mathrm{~m}$, or at the sub-surface chlorophyll maximum for shipboard (simulated in situ) measurements of carbon assimilation. The ${ }^{14} \mathrm{C}$ method described by Strickland \& Parsons (1968) was followed, and details of the incubation procedure and method of estimating daily euphotic zone production are given by Gowen et al. (1995). For the RV 'Cirolana' cruises, and RV 'Lough Foyle' March, June and October cruises, daily production was derived from regression analysis of chlorophyll standing stock against estimates of daily production (see Gowen \& Bloomfield 1996) using the equation:

$$
\begin{aligned}
\ln \text { production }= & 0.974(\ln \text { chlorophyll standing } \\
& \text { stock }+2.07)
\end{aligned}
$$

Sediment collection and storage. Sediment samples were collected during 3 RV 'Cirolana' cruises; October 1996, April 1997 and July 1998. Sediment and overlying water samples were collected using a NIOZ (Netherlands Institute for Sea Research) cylindrical box corer (31 cm i.d.). The box corer collected 30 to $50 \mathrm{~cm}$ of sediment and 15 to 251 of site water. Cores that had drained were discarded and the box corer redeployed. Three large sediment sub-cores (30 cm deep) and overlying water (1 l) were collected to measure benthic oxygen uptake at each respective site using Perspex tubes (65 $\mathrm{cm}$ long $\times 8 \mathrm{~cm}$ i.d.), each sealed at the bottom with a silicon rubber bung. Smaller sediment subcores ( 10 cm deep) with overlying water $(\sim 100 \mathrm{ml})$ were collected to measure benthic denitrification using Perspex tubes $(20 \mathrm{~cm}$ long $\times 3.4 \mathrm{~cm}$ i.d.). The cores collected for measuring oxygen uptake and denitrification were immersed open in aerated water baths containing bottom site water. Cores were allowed to re-equilibrate for $2 \mathrm{~h}$ at in situ temperature. Six additional sediment sub-cores $(\sim 20 \mathrm{~cm}$ deep) with overlying water $(\sim 750 \mathrm{ml})$ were collected from each site to measure sediment-water nutrient exchange using Perspex tubes (30 cm long $\times 10 \mathrm{~cm}$ i.d.), sealed underneath with an adjustable piston. Each of the nutrient exchange cores, with an independent air supply, were also stored in water baths, but they were kept closed and isolated from the incubation water. Additional, single, sediment cores $(30 \mathrm{~cm} \times 6 \mathrm{~cm}$ i.d.), to a depth of at least $15 \mathrm{~cm}$, were collected to determine various characteristics (described below), and were processed immediately.

Sediment characteristics. Sediment porosity, organic $\mathrm{C}$, total nitrogen $(\mathrm{N})$ and pigment concentrations were measured at $1 \mathrm{~cm}$ depths on extruded samples down to $10 \mathrm{~cm}$. Porosity was determined from dry weight and wet weight of known sediment volume. Samples for C and $\mathrm{N}$ analysis were sub-samples of the sectioned core used to determine porosity. Sediment was ground to pass through a $63 \mu \mathrm{m}$ sieve, homogenised and further sub-samples ( $2 \mathrm{~g}$ ) acidified with $\mathrm{HCl}$ (5 ml, 1M) to remove carbonate. After re-drying, subsamples (20 mg) were analysed for their organic C and $\mathrm{N}$ contents with a CHN analyser (Model 2400, PerkinElmer Ltd., Norwalk, Connecticut, USA) calibrated with standard acetanilide (71.09\% C, $10.36 \%$ N). Sediment chlorophyll and pheopigments were extracted (2:1 sediment volume to acetone) and measured as described above.

In situ pore-water nutrient profiles. Sediment porewater profiles were collected using an in situ vacuum 'sipper' system (Sivyer 1999). Extraction of a sufficient volume $(10 \mathrm{ml})$ of pore water was usually complete after 5 to $10 \mathrm{~min}$, depending on sediment type. Extracted water samples were filtered (0.2 $\mu \mathrm{m}$ Minisart Plus, Sartorius, UK Ltd), fixed ( $\mathrm{HgCl}$ solution, $100 \mu \mathrm{l}$, $0.2 \% \mathrm{w} / \mathrm{v}$, Kirkwood 1992), and subsequently analysed for $\mathrm{NO}_{3}{ }^{-}, \mathrm{NO}_{2}{ }^{-}, \mathrm{NH}_{4}{ }^{+}, \mathrm{Si}$ and $\mathrm{P}$ (as above).

Sedimentary rate measurements. Oxygen uptake: The 3 large core tubes $(65 \mathrm{~cm}$ long $\times 8 \mathrm{~cm}$ i.d.) were capped and completely water-filled to exclude air bubbles. A mid-column water sample $(20 \mathrm{ml})$ was then drawn off into a gas-tight syringe, gently transferred to an Exetainer (12 ml Labco Ltd, High Wycombe, UK) and fixed for Winkler analysis of dissolved oxygen. The water column in each tube was stirred with an induction motor driving a magnetic follower (Rank Brothers Ltd., Cambridge, UK) at $300 \mathrm{rpm}$ (Nedwell \& Trimmer 1996). Rates of benthic $\mathrm{O}_{2}$ uptake were measured using dissolved $\mathrm{O}_{2}$ electrodes (Model 1302, Strathkelvin Ltd., Glasgow, UK) coupled to a 6-channel $\mathrm{O}_{2}$ meter (Essex Electronics Centre, Colchester, UK). The multi-channel $\mathrm{O}_{2}$ meter was connected to a computer 
(V.I.P. Computers, UK) with data-analysis software (Notelog ${ }^{\circledR}$, Garrat Consultants, Colchester, UK) which logged, displayed and analysed the data. Onscreen computer logging enabled the oxygen concentration in the water column to be continuously monitored and statistically analysed for linearity with respect to time. Significant rates of oxygen uptake $(p<0.05)$ were usually determined within 1 to $4 \mathrm{~h}$. Triplicate incubation chambers containing only site water $(500 \mathrm{ml})$, with no sediment present, were treated and incubated as above, to act as controls for water-column remineralisation processes in the absence of sediment/water exchange.

Sediment-water nutrient exchange: After a $2 \mathrm{~h}$ reequilibration period, with gentle aeration and stirring of the water column, a water sample $(10 \mathrm{ml})$ was withdrawn, filtered and fixed prior to analyses. Incubation, with constant gentle aeration, was continued for up to $24 \mathrm{~h}$ with water samples taken every $4 \mathrm{~h}$. Incubations were carried out in the dark to counter the effect of any microalgae. All water samples were subsequently analysed for $\mathrm{NO}_{3}{ }^{-}, \mathrm{NO}_{2}{ }^{-}, \mathrm{NH}_{4}{ }^{+}, \mathrm{Si}(\mathrm{OH})_{4}$ and $\mathrm{PO}_{4}{ }^{3-}$ (as above).

Denitrification: Nine small sediment cores $(20 \mathrm{~cm}$ long $\times 3.4 \mathrm{~cm}$ i.d.) were used to measure denitrification rates using the ${ }^{15} \mathrm{NO}_{3}{ }^{-}$isotope-pairing technique of Nielsen (1992). Of the 9 cores, 6 were spiked by addition of ${ }^{15} \mathrm{NO}_{3}{ }^{-}\left(10 \mu \mathrm{M} \mathrm{Na}{ }^{15} \mathrm{NO}_{3}{ }^{-}\right.$[99.3 atom\%, Europa, Crewe, UK]) into the overlying water and left to equilibrate for $0.5 \mathrm{~h}$ (Rysgaard et al. 1995). Measurements of dissolved oxygen showed the water was at $100 \%$ of air saturation at the start of each incubation. A requirement of this technique is uniform mixing of the ${ }^{14} \mathrm{NO}_{3}{ }^{-}$ and ${ }^{15} \mathrm{NO}_{3}{ }^{-}$isotopes throughout the denitrification zone (Nielsen 1992). To test for this, a range of ${ }^{15} \mathrm{NO}_{3}{ }^{-}$ concentrations (5 to $40 \mu \mathrm{M}$ ) was added to give a final concentration range between 14 and $60 \mu \mathrm{m}\left({ }^{14} \mathrm{NO}_{3}{ }^{-}+\right.$ ${ }^{15} \mathrm{NO}_{3}{ }^{-}$). Calculated rates of coupled denitrification were found to be independent of the ${ }^{15} \mathrm{NO}_{3}{ }^{-}$concentration added and this was taken as evidence of uniform mixing (Nielsen 1992, Nielsen \& Glud 1996). Following this, cores were amended at the higher concentration of $40 \mathrm{\mu M}^{15} \mathrm{NO}_{3}{ }^{-}$(giving a final concentration range of
40 to $60 \mu \mathrm{m}{ }^{14} \mathrm{NO}_{3}{ }^{-}+{ }^{15} \mathrm{NO}_{3}{ }^{-}$depending on site and season) to minimise underestimation of denitrification (Nielsen \& Glud 1996).

Water samples $(2 \mathrm{ml})$, collected from all core tubes to determine the ${ }^{14} \mathrm{NO}_{3}{ }^{-}:{ }^{15} \mathrm{NO}_{3}{ }^{-}$ratio in the overlying water of the treatment cores, were filtered and preserved prior to analyses (see above). Sediment in the 3 reference cores were then gently mixed into a slurry with the overlying water and a $20 \mathrm{ml}$ sample drawn into an Exetainer (12 $\mathrm{ml}$ Labco Ltd, High Wycombe, UK) containing $\mathrm{ZnCl}_{2}$ solution $(500 \mu \mathrm{l}, 25 \% \mathrm{w} / \mathrm{v})$ and sealed. The ${ }^{15} \mathrm{NO}_{3}{ }^{-}$enriched cores were sealed and incubated in the dark at in situ temperature, with gentle stirring ( 60 rpm) of the water column for 2 to $6 \mathrm{~h}$. Onscreen data logging in the parallel oxygen-uptake cores ensured the concentration of oxygen in the overlying water remained $\geq 80 \%$ of air-saturation (see above). Following incubation, the ${ }^{15} \mathrm{NO}_{3}^{-}$-enriched cores were processed as for the reference cores. All slurry samples were sent to the National Environmental Research Institute, Silkeborg, Denmark, for analyses of abundance and concentration of ${ }^{28} \mathrm{~N}_{2},{ }^{29} \mathrm{~N}_{2}$ and ${ }^{30} \mathrm{~N}_{2}$ on a gas chromatograph coupled to a dual-inlet isotope-ratio mass spectrometer (Europa Instruments, Crewe, UK). Denitrification rates were calculated according to Nielsen (1992).

\section{RESULTS}

\section{Physical environment of the two bays}

In general, the Liverpool Bay station was less saline than the Irish coastal station (Table 1), and median salinities for the period March to October were 32.83 and 33.90 for Liverpool Bay and the Irish coast respectively. Vertical gradients in salinity were similar at the 2 stations (Liverpool Bay, mean 0.26 psu, $\mathrm{n}=8$; Irish coastal station, mean $0.23 \mathrm{psu}, \mathrm{n}=8$ ) Vertical gradients in temperature (mean $0.1^{\circ} \mathrm{C}, \mathrm{n}=8$ ) were small in Liverpool Bay compared to an average $(n=8)$ surfaceto-bottom difference of $0.5^{\circ} \mathrm{C}$ at the Irish coastal station.

Table 1. Summary of salinity and temperature data from the 2 coastal sites

\begin{tabular}{|c|c|c|c|c|}
\hline \multirow[t]{2}{*}{ Variable } & \multicolumn{2}{|c|}{ Irish coastal station } & \multicolumn{2}{|c|}{ Liverpool Bay } \\
\hline & $\begin{array}{c}\text { Spring } \\
\text { (Mar-May) }\end{array}$ & $\begin{array}{c}\text { Summer } \\
\text { (May-Aug) }\end{array}$ & $\begin{array}{c}\text { Spring } \\
\text { (Mar-May) }\end{array}$ & $\begin{array}{l}\text { Summer } \\
\text { (May-Aug) }\end{array}$ \\
\hline Near-surface salinity, S (psu) & $33.34-34.39$ & $33.69-33.80$ & $32.00-34.02$ & $32.45-32.95$ \\
\hline Near-surface temperature, $\mathrm{T}\left({ }^{\circ} \mathrm{C}\right)$ & $7.5-10.6$ & $11.4-15.4$ & $6.8-10.2$ & $10.7-17.8$ \\
\hline Surface-bottom S (psu) & $0.05-0.56$ & $0.18-0.42$ & $0.0-0.14$ & $0.01-0.22$ \\
\hline Surface-bottom T $\left({ }^{\circ} \mathrm{C}\right)$ & $0.0-0.5$ & $0.5-1.4$ & $0.1-0.2$ & $0.0-0.2$ \\
\hline Median salinity (Mar-Oct) & 33.90 & & 32.83 & \\
\hline
\end{tabular}


Table 2. Estimates of PAR attenuation $\left(k_{\mathrm{d}} \mathrm{m}^{-1}\right)$ and mean water-column irradiance (Irrad, $\mathrm{Wh} \mathrm{m}^{-2} \mathrm{~d}^{-1}$ ) in Irish coastal waters and Liverpool Bay during 1997

\begin{tabular}{|lcccc|}
\hline \multirow{2}{*}{ Date } & \multicolumn{2}{c}{$\begin{array}{c}\text { Irish coastal waters } \\
k_{\mathrm{d}}\left(\mathrm{m}^{-1}\right)\end{array}$} & Irrad & \multicolumn{2}{c|}{$\begin{array}{c}\text { Liverpool Bay } \\
\end{array}$} & $k_{\mathrm{d}}\left(\mathrm{m}^{-1}\right)$ & Irrad \\
\hline Mar 3 & 0.57 & 79 & & \\
Apr 5 & 0.19 & 435 & & \\
Apr 9 & & & 0.33 & 256 \\
Apr 30 & 0.42 & 188 & & \\
May 4 & & & 0.53 & 149 \\
May 20 & 0.30 & 233 & & \\
May 22 & & & 0.38 & 184 \\
Jun 4 & & & 0.33 & 324 \\
Jun 5 & 0.33 & 324 & & \\
Aug 9 & & & & \\
Aug 11 & 0.34 & 248 & & \\
\hline
\end{tabular}

Mean daily irradiance of the water column $\left(I_{\mathrm{w}}\right.$, Watt hours $[\mathrm{Wh}] \mathrm{m}^{-2}$ ) was calculated from the equation of Riley (1957):

$$
I_{\mathrm{w}}=I_{\mathrm{o}}\left(1-\mathrm{e}^{K_{\mathrm{d}} \mathrm{z}}\right) /\left(k_{\mathrm{z}}\right)
$$

where $I_{\mathrm{o}}$ is daily (PAR) irradiance, $K_{\mathrm{d}}$ is the diffuse attenuation coefficient and $z$ is depth. Except for early March, mean irradiance of the water column remained above $149 \mathrm{Wh} \mathrm{m}^{-2} \mathrm{~d}^{-1}$ during the study (Table 2 ).

Nutrients. There was little evidence of vertical gradients in dissolved N, P or Si at either station. Concentrations measured in samples from all depths have therefore been used to illustrate the seasonal cycle of each nutrient (Fig. 2) and changes in nutrient ratios during the spring bloom (Fig. 3). Maximum concentrations of $\mathrm{N}(29.2 \mu \mathrm{M})$ and $\mathrm{P}(1.7 \mu \mathrm{M})$ measured at
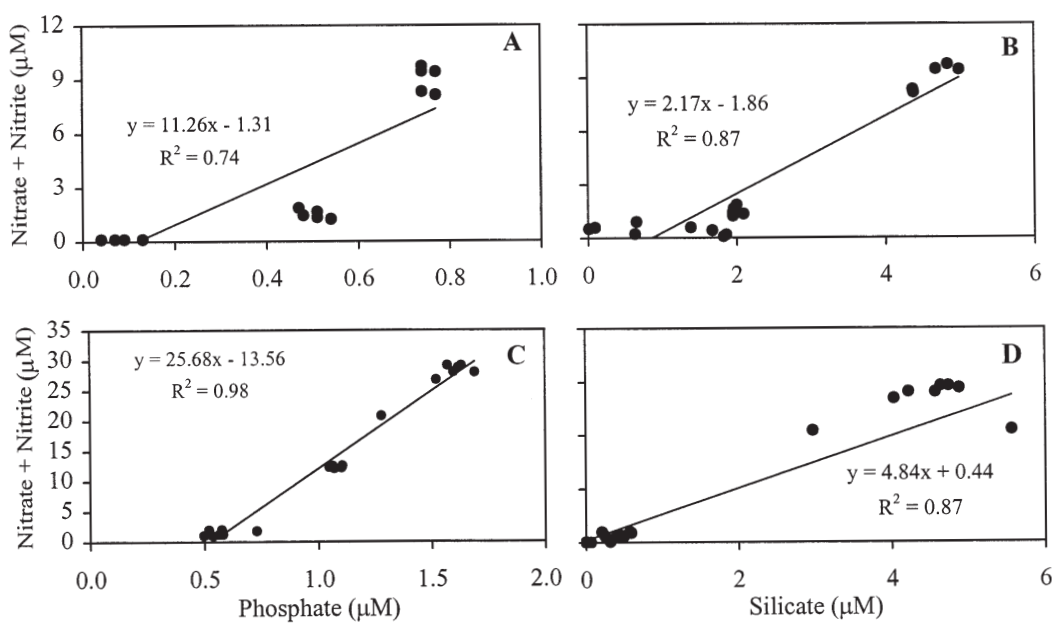

Fig. 3. Dissolved inorganic nitrate (+ nitrite) vs phosphate, and nitrate (+ nitrite) vs silicate concentrations during the spring bloom in Irish coastal waters (A, B) and Liverpool Bay $(\mathrm{C}, \mathrm{D})$
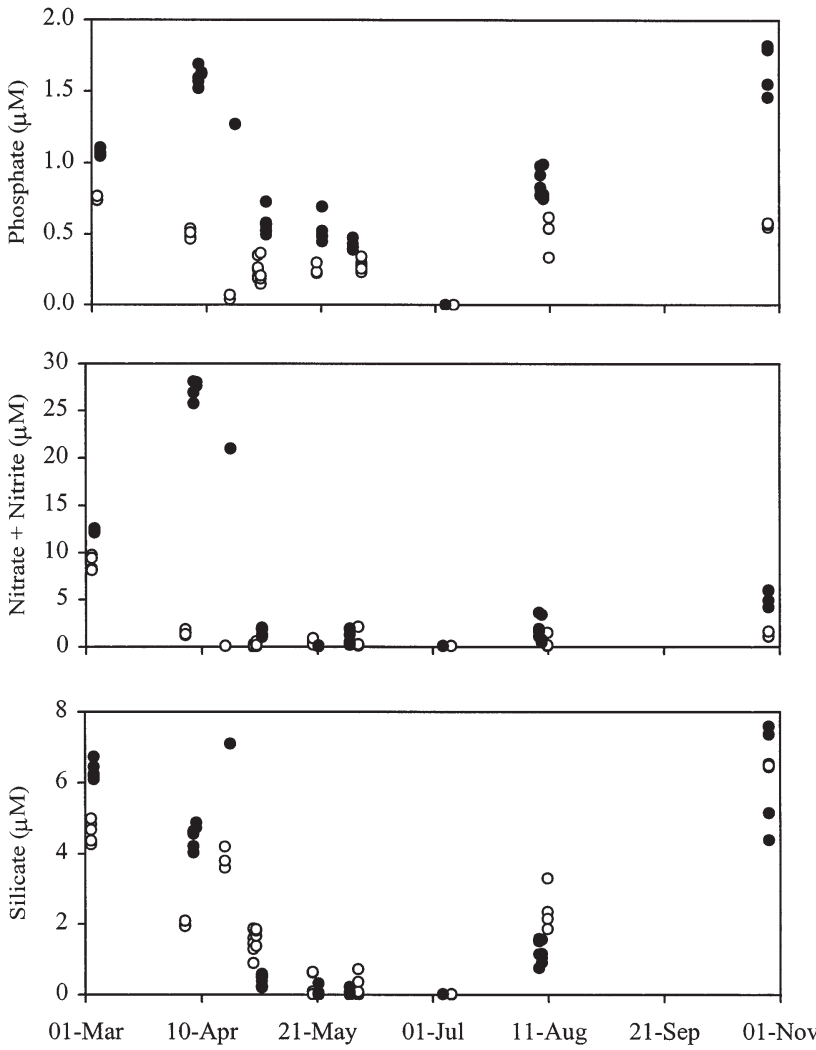

Fig. 2. Seasonal cycle of nitrate (+ nitrite), phosphate and silicate in Irish coastal waters (o) and Liverpool Bay (•) during 1997

the Liverpool Bay station were higher than concentrations at the Irish coastal station $(9.5 \mu \mathrm{M} \mathrm{N}$ and $0.8 \mu \mathrm{M}$ $\mathrm{P})$. $\mathrm{N}$ and $\mathrm{P}$ increased in Liverpool Bay during early April. This was not observed with Si in the Bay or the 3 nutrients at the Irish coastal station. There were marked decreases in concentrations of all 3 nutrients during March to May (Fig. 2). Nitrogen was depleted to $0.1 \mu \mathrm{M}$ on 19 April at the Irish coastal station, when $\mathrm{P}$ was $0.3 \mu \mathrm{M}$ and $\mathrm{Si}$ was $1.4 \mu \mathrm{M}$. Concentrations of $\mathrm{P}$ and $\mathrm{Si}$ continued to decline after this date, and reached minimum values in July and June, respectively. Depletion of $\mathrm{N}$ and $\mathrm{Si}$ occurred during late May in Liverpool Bay, when P was $0.5 \mu \mathrm{M}$. Based on 4 sets of samples collected during April and May (the spring bloom period) N, P and Si concentrations decreased in the ratio of 11.3 for $\mathrm{N}: \mathrm{P}$ and 2.2 for N:Si (Fig. 3A,B) at the Irish coastal station. Maximum N:P and N:Si ratios of 17.0 and 6.0 re- 
spectively, were recorded in Liverpool Bay prior to the bloom in early April. During the bloom, nutrient concentrations decreased in the ratios of 25.7 for $\mathrm{N}: \mathrm{P}$ and 4.8 for N:Si (Fig. 3C,D).

\section{Chlorophyll biomass and production}

A well-defined seasonal cycle of production and chlorophyll standing stock was observed at both stations, with a pronounced spring peak in standing stock during late April/early May (Fig. 4). Biomass was generally higher in Liverpool Bay, with a maximum spring biomass of $43.9 \mathrm{mg} \mathrm{m}^{-3}$ and mean summer biomass of $8.8 \mathrm{mg} \mathrm{m}^{-3}$ (range 4.1 to $13.6 \mathrm{mg} \mathrm{m}^{-3}, \mathrm{n}=29$ ). This compared with a maximum spring biomass of $11.4 \mathrm{mg} \mathrm{m}^{-3}$ and mean summer biomass of $2.5 \mathrm{mg} \mathrm{m}^{-3}$ (range 0.6 to $4.2 \mathrm{mg} \mathrm{m}^{-3}, \mathrm{n}=19$ ) at the Irish coastal station. In Liverpool Bay, the maximum rate of daily production (3165.8 $\mathrm{mg} \mathrm{C} \mathrm{m}^{-2} \mathrm{~d}^{-1}$ ) was measured during the spring bloom (Table 3), and production between March and October was estimated as $182 \mathrm{~g} \mathrm{C} \mathrm{m}^{-2}$. Maximum daily production during spring was $1175.0 \mathrm{mg} \mathrm{C} \mathrm{m}^{-2} \mathrm{~d}^{-1}$, and March to October production was $97 \mathrm{~g} \mathrm{C} \mathrm{m}^{-2}$ at the Irish coastal station.

\section{Phytoplankton species}

At both stations, blooms of microflagellates (predominantly Phaeocyctis spp.) occurred before the spring peak in diatoms (Table 4). Guinardia (= Rhizosolenia) delicatula dominated the spring bloom at both stations, and excluding microflagellates, represented $>90 \%$ of total phytoplankton abundance. Large diatom species such as Eucampia zoodiacus $\left(99.6 \times 10^{3}\right.$ cells $\left.\mathrm{l}^{-1}\right)$, Guinardia flaccida $\left(23.2 \times 10^{3}\right.$ cells $\left.\mathrm{l}^{-1}\right)$ and Rhizosolenia styliformis $\left(322.9 \times 10^{3}\right.$ cells $\left.\mathrm{l}^{-1}\right)$ were prominent during the spring bloom in Liverpool Bay but generally absent from the Irish coastal region.

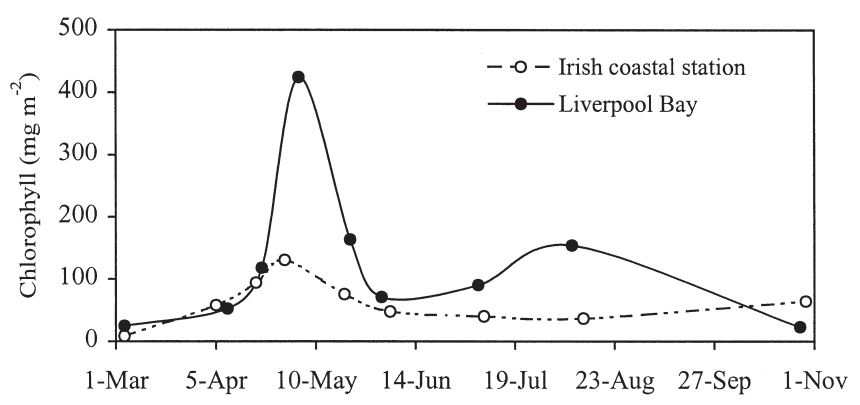

Fig. 4. Seasonal changes in chlorophyll standing stock $\left(\mathrm{mg} \mathrm{m}^{-2}\right)$ at the Irish coastal waters and Liverpool Bay during 1997
Table 3. Estimates of daily production $\left(\mathrm{mg} \mathrm{C} \mathrm{m}^{-2} \mathrm{~d}^{-1}\right)$ in Irish coastal waters and Liverpool Bay during 1997

\begin{tabular}{|c|c|c|}
\hline Date & Irish coastal waters & Liverpool Bay \\
\hline Mar 4 & $83.2^{\mathrm{a}}$ & $138.0^{\mathrm{a}}$ \\
\hline Apr 5 & 497.6 & 342.2 \\
\hline \multicolumn{3}{|l|}{ Apr 9} \\
\hline Apr 19 & $624.2^{\mathrm{a}}$ & \\
\hline Apr 21 & & $779.4^{\mathrm{a}}$ \\
\hline Apr 30 & 1175.0 & \\
\hline May 4 & & 3165.8 \\
\hline May 20 & 194.0 & \\
\hline May 22 & & 1287.8 \\
\hline Jun 4 & & $471.8^{\mathrm{a}}$ \\
\hline Jun 5 & $321.4^{\mathrm{a}}$ & \\
\hline Jul 6 & & $599.9^{a}$ \\
\hline Jul 8 & $269.9^{\mathrm{a}}$ & \\
\hline Aug 8 & & 971.5 \\
\hline Aug 11 & 380.5 & \\
\hline Oct 28 & & $185.0^{\mathrm{a}}$ \\
\hline Oct 29 & $429.0^{\mathrm{a}}$ & \\
\hline \multicolumn{3}{|c|}{$\begin{array}{l}\text { aproduction calculated using the equation [ln production = } \\
0.974 \text { (ln chlorophyll }+2.07 \text { )] derived from linear-regres- } \\
\text { sion analysis of relationship between euphotic zone chlo- } \\
\text { rophyll and euphotic zone daily production measured at } \\
\text { the } 2 \text { stations }\end{array}$} \\
\hline
\end{tabular}

\section{Sediment characteristics}

Porosity and organic $\mathrm{C}$ were typically low for the sandy sediment at the Irish coastal site and in Liverpool Bay (0.43 and 0.38 and $1.2 \%$ dry wt and $0.8 \%$ dry wt for the 2 sites respectively, mean value $n=30$ ), but were significantly $(p<0.05)$ greater at the Irish coastal site. Limited sediment-pigment data were collected from the 2 sites, but exhibited a consistent pattern, with 3 to 6 times more pigment in the Irish coastal sediment. In May 1996, for example, the upper $1 \mathrm{~cm}$ of Irish coastal sediment contained $57.5 \mathrm{mg}$ pigment $\mathrm{m}^{-2}$ compared to $9.2 \mathrm{mg} \mathrm{m}^{-2}$ in Liverpool Bay sediment. At both sites, pigment content decreased with increasing depth (Fig. 5), but at each depth horizon sampled, there were greater amounts of pigment in the Irish coastal sediment.

\section{Pore-water nutrients}

At the Irish coastal site, pore-water concentrations of $\mathrm{NH}_{4}{ }^{+}$, Si and $\mathrm{P}$ were markedly higher (single sample) in Irish coastal sediments compared to sediment in Liverpool Bay (Fig. 6), and increased with increasing sediment depth at both sites. In contrast, $\mathrm{NO}_{3}{ }^{-}$concentrations were similar at both sites and varied little with sediment depth. 
Table 4. Abundance $\left(\times 10^{3}\right.$ cells $\left.\mathrm{l}^{-1}\right)$ of dominant phytoplankton species identified in Irish coastal waters and Liverpool Bay during spring and summer 1997

\begin{tabular}{|c|c|c|c|c|c|c|c|}
\hline $\begin{array}{l}\text { Irish coastal waters } \\
\text { Species }\end{array}$ & 5 Apr & 19 Apr & $30 \mathrm{Apr}$ & 20 May & 4 Jun & $8 \mathrm{Jul}$ & 11 Aug \\
\hline Chaetoceros decipiens & 1.5 & 0.2 & 0.2 & & 0.4 & 36.2 & 12.8 \\
\hline Chaetoceros debilis & 0.7 & & & & & 49.8 & 22.7 \\
\hline Leptocylindrus danicus & 0.2 & 0.4 & & 0.4 & 59.7 & 166.2 & 2.9 \\
\hline Leptocylindrus minimus & & & 0.2 & & & 2.0 & 9.2 \\
\hline Guinardia delicatula & 14.8 & 151.0 & 709.1 & 0.5 & 1.4 & 3.1 & 1.5 \\
\hline Rhizosolenia setigera & 1.3 & 8.6 & & & & 2.1 & 1.1 \\
\hline Rhizosolenia styliformis & 0.5 & 2.5 & 4.6 & 7.7 & 48.1 & 0.3 & 1.2 \\
\hline Rhizosolenia stolterfothii & 0.2 & 1.0 & 2.2 & 0.7 & 1.4 & 1.2 & \\
\hline Large Gymnodinium/Gyrodinium spp. & 7.8 & 2.5 & 2.3 & 1.8 & 0.8 & 2.4 & 0.8 \\
\hline Small dinoflagellates $(\leq 15 \mu \mathrm{m})$ & 14.0 & 30.4 & 34.4 & 21.3 & 23.1 & 23.0 & 14.0 \\
\hline Ciliates & 1.2 & 4.4 & 0.9 & 5.7 & 2.6 & 8.9 & 3.1 \\
\hline Microflagellates $(<12 \mu \mathrm{m})$ & 20.2 & 4081.3 & 23.1 & 177.7 & 41.4 & 211.2 & 248.3 \\
\hline \multicolumn{8}{|l|}{ Liverpool Bay } \\
\hline Species & 9 Apr & $21 \mathrm{Apr}$ & May 4 & 22 May & 5 Jun & $6 \mathrm{Jul}$ & 8 Aug \\
\hline Bacteriastrum hyalinum & & & & & & & 11.0 \\
\hline Ceratulina bergonii & 1.6 & 5.4 & 16.5 & & & & \\
\hline Chaetoceros decipiens & 0.7 & 2.2 & 1.1 & 0.2 & & & 67.7 \\
\hline Chaetoceros debilis & 0.9 & 3.8 & & & & 0.5 & 123.1 \\
\hline Ditylum brightwelli & 1.9 & 0.4 & & & & & \\
\hline Eucampia zoodiacus & 2.5 & 18.4 & 99.6 & 8.2 & 0.3 & 0.40 & 19.8 \\
\hline Guinardia delicatula & 11.3 & 40.4 & 296.3 & 785.1 & 79.3 & 29.2 & 817.7 \\
\hline Guinardia flaccida & 0.4 & 1.7 & 15.8 & 23.2 & 6.6 & 0.8 & 0.4 \\
\hline Leptocylindrus danicus & 0.4 & 1.4 & 0.2 & 1.3 & 6.1 & 727.7 & 38.0 \\
\hline Leptocylindrus minimus & & & 0.2 & 1.8 & 0.3 & 28.6 & 202.4 \\
\hline Rhizosolenia setigera & 2.6 & 6.3 & 19.0 & 9.5 & & 0.2 & 1.7 \\
\hline Rhizosolenia styliformis & 17.8 & 7.5 & 55.8 & 322.9 & 0.9 & 0.3 & 10.4 \\
\hline Pseudo-Nitzschia spp. & 9.4 & 13.6 & 45.7 & 159.2 & 0.3 & 1.1 & 10.8 \\
\hline large Gymnodinium/Gyrodinium spp. & 2.3 & 3.3 & 1.9 & 5.1 & 8.8 & 4.0 & 3.1 \\
\hline Small dinoflagellates $(\leq 15 \mu \mathrm{m})$ & 1.3 & 4.4 & 15.8 & & 14.0 & 7.0 & 13.9 \\
\hline Ciliates & 0.4 & 6.9 & 1.6 & 4.4 & 14.1 & 4.7 & 4.8 \\
\hline Microflagellates $(<12 \mu \mathrm{m})$ & 585.0 & 7919.0 & 10000.0 & 585.4 & 826.4 & 1997.1 & 1687.2 \\
\hline
\end{tabular}

\section{Rate measurements}

Rates of oxygen uptake (Table 5) were statistically identical at both sites on each occasion, but were significantly $(\mathrm{p}<0.05)$ elevated at both sites in the summer relative to spring and autumn. The calculated rates of coupled denitrification $\left(D_{\mathrm{n}}\right)$ at both sites proved to be independent of the concentration of ${ }^{15} \mathrm{NO}_{3}{ }^{-}$ added, which indicated a uniform mixing of the ${ }^{14} \mathrm{NO}_{3}{ }^{-}$ and ${ }^{15} \mathrm{NO}_{3}{ }^{-}$isotope pools. Total denitrification was dominated by $D_{\mathrm{n}}$ at the Irish coastal site on each occasion $(90,97$ and $94 \%$ in autumn, spring and summer respectively). Significant rates of $D_{\mathrm{n}}$ could only be measured in Liverpool Bay sediments during the summer, and were significantly lower than those measured at the Irish coastal site $(\mathrm{p}<0.05)$. Rates of uncoupled denitrification $\left(D_{\mathrm{w}}\right)$ were low at both sites and statistically identical at all times.

At both sites, sediments were consistent sources of $\mathrm{NO}_{3}{ }^{-}, \mathrm{NH}_{4}{ }^{+}$and $\mathrm{Si}$ to the overlying water (Table 5). The

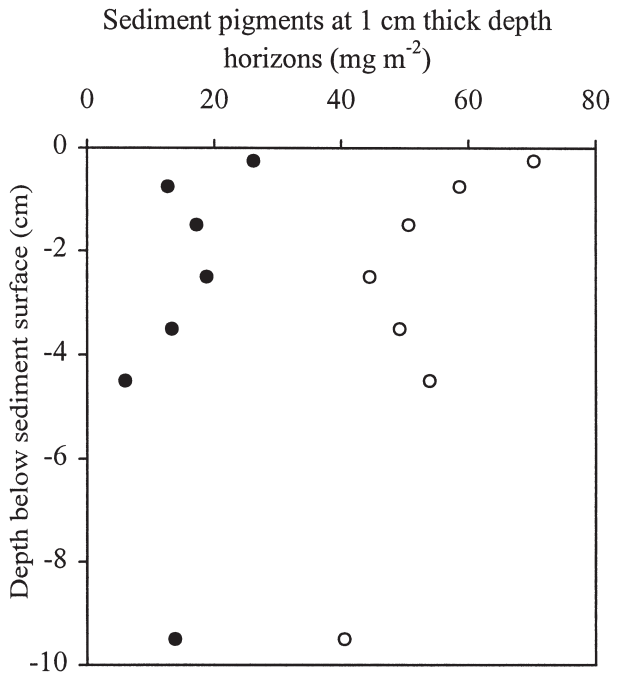

Fig. 5 Profiles of pigment (chlorophyll and pheopigment) measured in Irish coastal waters (o) and Liverpool Bay (0) sediment during the period 8 to 11 August, 1997 
efflux of $\mathrm{NH}_{4}{ }^{+}$and $\mathrm{Si}$ was greatest at the Irish coastal site and was significantly higher at both sites in summer $(p<0.05)$. The efflux of $\mathrm{NO}_{3}{ }^{-}$from Irish coastal sediment remained constant, but increased from spring to summer in Liverpool Bay.

\section{DISCUSSION}

\section{Productivity and nutrient utilisation}

It is evident that Liverpool Bay supported greater phytoplankton production, with generally higher biomass, compared to the Irish coastal region. Detailed observations of chlorophyll at the Irish coastal station are only available for 1992 and 1993 (Gowen \& Bloomfield 1996). The maximum 1992 and 1993 springbloom chlorophyll concentrations reported by these workers were 20.6 and $12.9 \mathrm{mg} \mathrm{m}^{-3}$ respectively, which compares with $11.4 \mathrm{mg} \mathrm{m}^{-3}$ measured in 1997. Few data are available for Liverpool Bay, which makes it difficult to assess whether the $43.9 \mathrm{mg} \mathrm{m}^{-3}$ measured in this study is typical of the spring bloom in this coastal region. Foster et al. (1982) give values of between 1.5 and $7.0 \mathrm{mg} \mathrm{m}^{-3}$ for early May 1977, and Kennington et al. $(1997,1998)$ reported up to $16 \mathrm{mg} \mathrm{m}^{-3}$ for more offshore waters in April 1997. Spencer (1972) recorded chlorophyll values of $<1.0 \mathrm{mg} \mathrm{m}^{-3}$ in June and July 1970, which seem particularly low for Liverpool Bay.

Annual (March to October) production in Liverpool Bay $\left(182 \mathrm{~g} \mathrm{C} \mathrm{m}^{-2}\right)$ was approximately double the estimated $97 \mathrm{~g} \mathrm{C} \mathrm{m}^{-2}$ for the Irish coastal station. The latter is low compared with the 155 to $195 \mathrm{~g} \mathrm{C} \mathrm{m}^{-2}$ given by Gowen \& Bloomfield (1996) for the same location in 1992 and 1993. The reason for the lower 1997 estimate is unclear, but is unlikely to result from differences between the production and chlorophyll data presented here and earlier data (Gowen \& Bloomfield 1996, Department of Agriculture for Northern Ireland unpubl. data) since these differences are generally small. For Liverpool Bay, there are no published productivity data with which to compare our data. For hypernutrified Dutch coastal waters, van Bennekom et al. (1975) gave daily production rates of up to $3.5 \mathrm{~g} \mathrm{C}$ $\mathrm{m}^{-2}$ (our maximum spring bloom value was $3.2 \mathrm{~g} \mathrm{C} \mathrm{m}^{-2}$ : Table 3) and Joint \& Pomroy (1993) estimated seasonal production as 250 to $300 \mathrm{~g} \mathrm{C} \mathrm{m}^{-2} \mathrm{yr}^{-1}$ for continental coastal waters of the southern North Sea.

We attribute enhanced productivity in Liverpool Bay to its nutrient regime rather than to hydrographic differences between the 2 coastal areas. Greater vertical
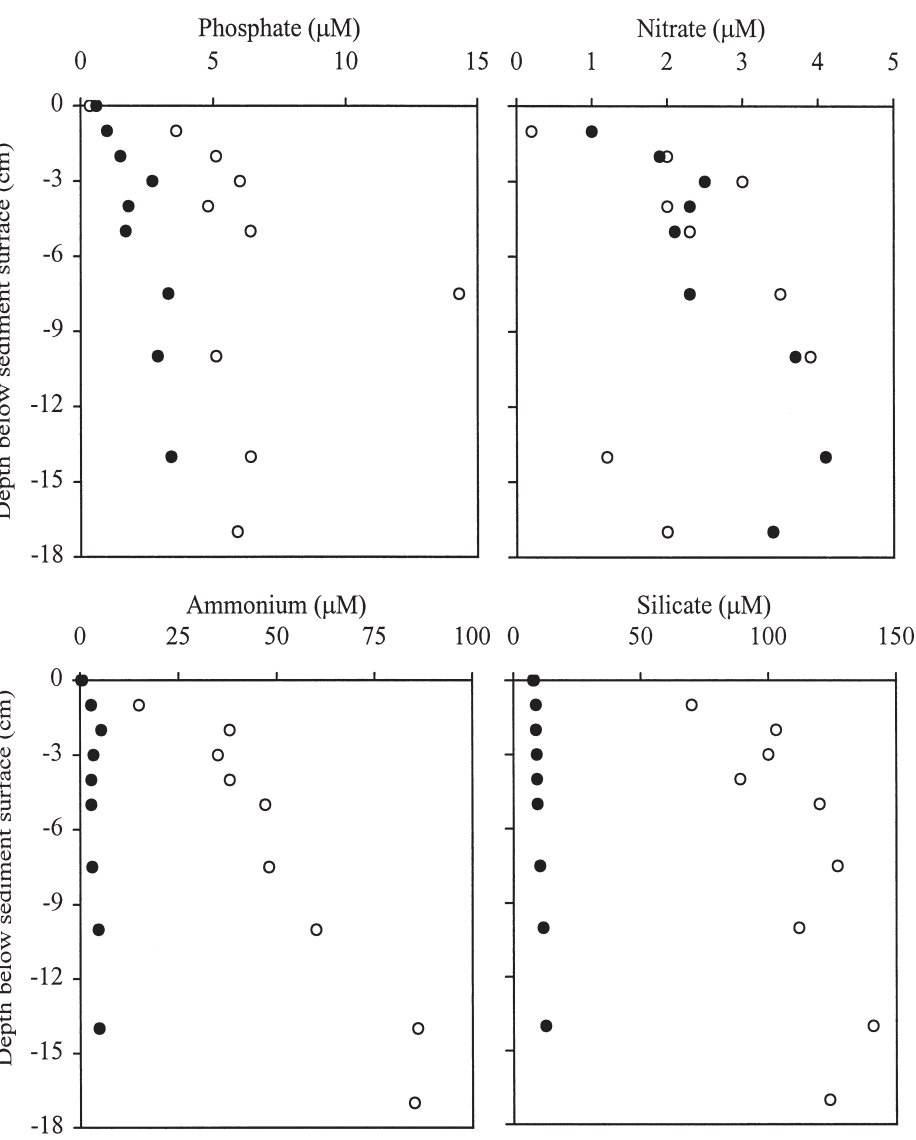

Fig. 6. Profiles of sediment pore-water nutrients measured at the Irish coastal waters (o) and Liverpool Bay ( $\bullet$ ) during the period 8 to 11 August, 1997

mixing of the water in Liverpool Bay can be inferred from smaller surface-to-bottom differences in salinity and temperature (Table 1). It is likely, however, that during spring and summer the influence of such mixing on the vertical distribution of phytoplankton (and hence daily light exposure) would have been limited by the shallow depth $(20 \mathrm{~m})$ of the station. Gowen et al. (1995) estimated the daily light threshold for net production of Irish Sea phytoplankton to be 183 to $245 \mathrm{Wh} \mathrm{m}^{-2}$ (see also Levasseur et al. 1984, Peperzak et al. 1998), and it is evident that during late spring and summer there was sufficient light to support net photosynthesis throughout the water column at both locations (Table 2).

There are no detailed data on dissolved nutrients for the Irish coastal region prior to 1991. Gillooly et al. (1992) reported $\mathrm{N}$ values of up to $30.0 \mu \mathrm{M}$ in Dundalk Day, $20.0 \mu \mathrm{M}$ in the coastal margin, and $10.0 \mu \mathrm{M}$ in more open Irish coastal waters. Data collected from the Irish coastal station in 1992 (Gowen et al. 1995) and the synoptic data for N, P and Si of Gibson et al. (1997) show little evidence of enrichment at the coastal site studied, with typical winter $\mathrm{N}$ concentrations of 8.0 to 
Table 5. Water-column gross production, benthic oxygen-uptake rates and benthic mineralisation and silicate efflux budgets for Irish coastal waters and Liverpool Bay

\begin{tabular}{|c|c|c|c|c|}
\hline & \multicolumn{2}{|c|}{ Irish coastal site } & \multicolumn{2}{|c|}{ Liverpool Bay } \\
\hline & Spring & Summer & Spring & Summer \\
\hline \multicolumn{5}{|c|}{ Pelagic carbon production and benthic mineralisation ( $\mathrm{mol} \mathrm{C} \mathrm{m}^{-2} \mathrm{~d}^{-1}$ ) } \\
\hline Gross primary production & 0.098 & 0.027 & 0.264 & 0.057 \\
\hline Oxygen uptake & 0.013 & 0.048 & 0.011 & 0.038 \\
\hline$\%$ primary production mineralised ${ }^{a}$ & 13 & 178 & 4 & 67 \\
\hline \multicolumn{5}{|c|}{ Benthic $\mathrm{N}$ mineralisation budget ( $\mu \mathrm{mol} \mathrm{N} \mathrm{m}^{-2} \mathbf{h}^{-1}$ ) } \\
\hline Nitrate efflux & 6 & 7 & 4 & 12 \\
\hline$\%$ of $\mathrm{N} \min$ & 20 & 19 & 44 & 53 \\
\hline Ammonium efflux & 17 & 22 & 5 & 8 \\
\hline$\%$ of $\mathrm{N} \min$ & 60 & 61 & 56 & 37 \\
\hline$\%$ of production $\mathrm{N}^{\mathrm{b}}$ & 4 & 18 & 1 & 6 \\
\hline Denitrification $\left(D_{\mathrm{n}}\right)$ & 6 & 7 & 0 & 2 \\
\hline$\%$ of $\mathrm{N} \min$ & 20 & 19 & 0 & 10 \\
\hline Total N mineralised & 29 & 36 & 9 & 22 \\
\hline$\%$ production $\mathrm{N}$ denitrified ${ }^{\mathrm{b}}$ & 8 & 3 & 0 & 1 \\
\hline \multicolumn{5}{|l|}{ Silicate } \\
\hline 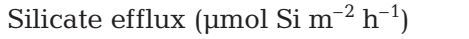 & 42 & 123 & 3 & 1 \\
\hline$\%$ of production $\mathrm{Si}^{\mathrm{c}}$ & 8 & 84 & 0 & 0 \\
\hline \multicolumn{5}{|c|}{$\begin{array}{l}{ }^{\text {a }} \text { Calculated assuming organic matter oxidised by sulphate reduction was included in the sedimentary uptake of oxygen } \\
\text { because of aerobic reoxidation of sulphide at the sediment surface } \\
{ }^{b} \text { Percentage of daily production supported by } \mathrm{NO}_{3}^{-} \text {and } \mathrm{NH}_{4}{ }^{+} \text {efflux and calculated assuming a phytoplankton C:N ratio of } 7: 1 \\
{ }^{\mathrm{c} C} \text { Calculated assuming a phytoplankton } \mathrm{C}: \mathrm{Si} \text { ratio of } 7.7: 1 \text { and that production was dominated by diatoms }\end{array}$} \\
\hline
\end{tabular}

$10.0 \mu \mathrm{M}$. The more extensive nutrient data for Liverpool Bay clearly show that its waters are enriched with $\mathrm{N}$ and P. Early studies report winter $\mathrm{N}$ concentrations in excess of $20.0 \mu \mathrm{M}$ and up to $32.1 \mu \mathrm{M}$ (Jones \& Folkard 1971, Abdullah \& Royle 1973, Foster 1984) and $\mathrm{P}$ concentrations of 1.2 to $2.0 \mu \mathrm{M}$ (Jones \& Folkard 1971, Foster 1984). The broad range of winter $N$ values (8.6 to $32.1 \mu \mathrm{M}$ ) reported for Liverpool Bay reflects the degree of mixing between freshwater and coastal water and the seaward extent of enriched waters (Foster et al. 1977), and may explain the apparent increase in $\mathrm{N}$ and $\mathrm{P}$ between March and April 1997. On 4 March, a nitrogen concentration of $12.4 \mu \mathrm{M}$ was associated with a salinity of $34.02 \mathrm{psu}$; on 9 April, $\mathrm{N}$ was $28.2 \mu \mathrm{M}$ and salinity $32.24 \mathrm{psu}$.

In March, N:P ratios were 12.0 (Irish coastal station) and 11.6 (Liverpool Bay), and compare well with the Redfield ratio of 16 (Redfield 1958). The decrease in nutrient concentrations during March to May is largely the result of the draw-down of winter nutrients by phytoplankton during the spring bloom. Over this period, mean nutrient ratios therefore approximate ratios of nutrient utilisation by phytoplankton. At the Irish coastal station, the $\mathrm{N}: \mathrm{P}$ utilisation ratio of 11.3 (Fig. 3A) is close to the lower value of 12 for phytoplankton given by Parsons et al. (1984). The N:Si utilisation ratio of 2.2 at the Irish coastal station, and in particular the ratio of 4.8 in Liverpool Bay, were higher than the mean N:Si ratio of 0.89 (0.69 to $1.27, \mathrm{n}=27$ ) given by Brzezinski (1985) for marine diatoms, and may reflect the uptake of $\mathrm{N}$ by flagellates before the diatom bloom. One consequence of the early flagellate bloom in Irish coastal waters appeared to be that $\mathrm{N}$ became depleted before Si (Fig. 3B). Si continued to decline during May, suggesting that following depletion of winter $\mathrm{N}$, the latter stages of the spring diatom bloom were supported by recycled nitrogen $\left(\mathrm{NH}_{4}{ }^{+}\right)$, perhaps from heterotrophic excretion or sediment mineralisation.

Prior to the spring bloom in Liverpool Bay, nutrient ratios were elevated (N:P 17.0 and N:Si 6.0), and indicate $\mathrm{N}$ enrichment of the Bay. In addition, the N:P utilisation ratio in Liverpool Bay was 25.7 (Fig. 3C); this is higher than values for phytoplankton given by Parsons et al. (1984), and implies removal of $\mathrm{N}$ by a process other than phytoplankton uptake or re-supply of $\mathrm{P}$. Ewins \& Spencer (1967) observed a high N:P utilisation ratio in the Menai Straits, and suggested exchange processes between dissolved and particulate phosphorous as a mechanism for maintaining soluble $\mathrm{P}$ in the water column. Coastal waters of Liverpool Bay receive large amounts of riverine particulate material, which could be a source of particulate and therefore dissolved P.

Our observations show $\mathrm{N}$ and $\mathrm{P}$ enrichment of Liverpool Bay and a consequent shift in N:P and N:Si ratios. 
Elevated primary production and algal standing crop were associated with enrichment, but changes in the nutrient status of the Bay had little influence on species composition in 1997. In both coastal areas the spring diatom bloom was dominated by the same species (Guinardia [= Rhizosolenia] delicatula). The presence of the large diatom species Ditylum brightwelli, Guinardia flaccida and Eucampia zoodiacus during the Liverpool Bay spring bloom and their absence from the Irish coastal site may have resulted from a pulsed nutrient supply to the Bay (Riegman et al. 1993).

Blooms of flagellates (predominantly Phaeocystis spp.) preceded the spring diatom bloom at both coastal sites in 1997. At the time of peak flagellate abundance, concentrations of $\mathrm{Si}$ were 3.1 and $0.4 \mu \mathrm{M}$ in Irish coastal waters and Liverpool Bay respectively. These observations are not entirely consistent with the Silimitation hypothesis (Officer \& Ryther 1980, Egge \& Asknes 1992), although Peperzak et al. (1998) observed diatoms and Phaeocystis spp. growing together in a suitable light environment in the presence of $\mathrm{Si}$. Furthermore, since blooms of flagellates were observed in both regions, enrichment was not the only factor determining occurrence but was the most likely reason for greater abundance in Liverpool Bay. It is difficult to determine whether spring flagellate blooms are typical of the 2 sites. The dominance of microflagellate growth at the time of the spring bloom is often attributed to nutrient enrichment (Riegman et al. 1992), although microflagellates have been reported to be a component of the spring phytoplankton bloom in unenriched coastal waters (see for example Woods et al. 1973). In addition, there are no long-term species records for either coastal area, although Phaeocystis spp. have been reported in Liverpool Bay (Spencer
1972, Foster et al. 1982, Kennington et al. 1997, 1998) and have on occasions formed large blooms (Jones \& Haq 1963).

Abundance-based estimates of species dominance can be misleading because of differences in cell size. To overcome this, species carbon was derived from estimates of biovolume using the equations of Strathman (1967). In general, Liverpool Bay was dominated by diatoms throughout the spring and summer (Table 6) with little evidence of a succession from diatoms to flagellates (microflagellates and dinoflagellates). During summer, flagellate carbon did not exceed $46 \%$ of total phytoplankton carbon, although microflagellates represented a greater proportion of algal carbon in Liverpool Bay than at the Irish coastal station. There is more evidence of a succession from diatom domination in spring to flagellate domination in late summer at the Irish coastal station, where flagellates represented $60 \%$ of the carbon biomass in July and August.

\section{Sedimentary processes}

The seasonal rates of oxygen uptake reported here are similar to the average rate reported for the summer stratified region of the western Irish Sea $\left(924 \mu \mathrm{mol} \mathrm{O}_{2}\right.$ $\mathrm{m}^{-2} \mathrm{~h}^{-1}$ : Trimmer et al. 1999) and for the southern North Sea (van Raaphort et al. 1992, Upton et al. 1993, Lohse 1994, Trimmer et al. 2000). Sediment temperatures were elevated at both sites during summer and winter relative to spring, but only the summer rates of oxygen uptake were significantly $(p<0.05)$ elevated. This suggests that in addition to temperature, inputs of particulate organic matter (POM) also regulated summer benthic respiration. It is unlikely that spring-

Table 6. Carbon biomass $\left(\mu \mathrm{C} \mathrm{C}^{-1}\right.$ ) of diatoms, dinoflagellates and microflagellates at the 2 coastal stations in the Irish Sea during spring and summer 1997

\begin{tabular}{|c|c|c|c|c|c|c|}
\hline \multirow{2}{*}{ Date } & \multirow{2}{*}{\multicolumn{2}{|c|}{ Irish coastal station }} & \multirow[b]{2}{*}{ Microflagellates } & \multirow[b]{2}{*}{ Diatoms } & \multirow{2}{*}{$\begin{array}{c}\text { - Liverpool Bay } \\
\text { Dinoflagellates }\end{array}$} & \multirow[b]{2}{*}{ Microflagellates } \\
\hline & & Dinoflagellates & & & & \\
\hline Apr 5 & 7.3 & 19.4 & 0.4 & & & \\
\hline Apr 9 & & & & 55.7 & 9.2 & 13.7 \\
\hline Apr 19 & 59.3 & 26.5 & 84.9 & & & \\
\hline Apr 21 & & & & 59.0 & 32.7 & 185.9 \\
\hline Apr 30 & 230.6 & 23.8 & 0.5 & & & \\
\hline May 4 & & & & 362.2 & 6.7 & 234.8 \\
\hline May 20 & 19.0 & 21.7 & 3.7 & & & \\
\hline May 22 & & & & 3090.0 & 20.5 & 13.7 \\
\hline Jun 4 & 118.6 & 19.8 & 1.0 & & & \\
\hline Jun 5 & & & & 60.5 & 30.5 & 19.4 \\
\hline Jul 6 & & & & & & \\
\hline Jul 8 & 46.3 & 65.9 & 5.0 & 107.1 & 31.9 & 46.9 \\
\hline Aug 8 & & & & & & \\
\hline Aug 11 & 36.8 & 49.1 & 5.8 & 470.5 & 43.0 & 39.6 \\
\hline
\end{tabular}


bloom production influenced summer respiration rates, as its effect is relatively short-lived (Trimmer et al. 1999).

Benthic mineralisation rates were statistically identical at the 2 sites. However, rates of $\mathrm{NH}_{4}{ }^{+}$efflux and coupled denitrification were higher at the Irish coastal site, suggesting the organic matter being mineralised had a lower $\mathrm{C}: \mathrm{N}$ ratio compared with Liverpool Bay. Average molar C:N ratios over the top $10 \mathrm{~cm}$ of sediment for the 2 sites were similar, 44:1 (Irish coastal site) and 47:1 (Liverpool Bay). However, bulk sedimentary organic-matter determinations do not discriminate labile and refractory organic matter (Nedwell 1987) and may therefore give little indication of the amount of microbially available organic matter at each site, especially on a short time scale. An estimate of labile organic $\mathrm{C}$ can be derived by multiplying sedimentary chlorophyll concentration by 40 (Hargrave \& Philips 1989). For the spring, the pool of labile material was greater at the Irish coastal site $\left(0.076 \mathrm{~mol} \mathrm{C} \mathrm{m}^{-2}\right)$ compared to Liverpool Bay $\left(0.016 \mathrm{~mol} \mathrm{C} \mathrm{m}^{-2}\right)$. Dividing the labile organic $\mathrm{C}$ pool, for the top $1 \mathrm{~cm}$ of sediment, by the respective oxygen uptake rate gives decay times of 6 and $1.5 \mathrm{~d}$ for the Irish coastal site and Liverpool Bay respectively.

Denitrification supported by the flux of $\mathrm{NO}_{3}{ }^{-}$from the overlying water into the sediment $\left(D_{\mathrm{w}}\right)$ remained low throughout the study at both sites. Low rates of $D_{\mathrm{w}}$ measured in the spring, despite $\mathrm{NO}_{3}{ }^{-}$concentrations in the overlying water of up to $29 \mu \mathrm{M}$, could be explained by low rates of oxygen uptake at the 2 sites and therefore a low demand for $\mathrm{NO}_{3}^{-}$by facultative anaerobes. Although oxygen uptake increased in the summer, $\mathrm{NO}_{3}{ }^{-}$concentrations were at their seasonal minima $(0.4$ and $1.0 \mu \mathrm{M}$ at the Irish coastal site and Liverpool Bay respectively) which, in turn, limited measurable rates of $D_{\mathrm{w}}$. Denitrification coupled to nitrification of mineralised $\mathrm{NH}_{4}{ }^{+}\left(D_{\mathrm{n}}\right)$ dominated denitrification at the Irish coastal site (and in Liverpool Bay in summer). The higher rates of $D_{\mathrm{n}}$ at the Irish coastal site could be explained by greater availability of organic material at this site relative to Liverpool Bay, which in turn stimulated higher rates of ammonification (Fig. 6) and then $D_{\mathrm{n}}$ (Sloth et al. 1995).

\section{Coupling between primary production and sedimentary processes}

Nixon (1981) derived a linear relationship between available pelagic organic $\mathrm{C}$ and benthic oxygen uptake in shallow marine coastal environments, suggesting close coupling between pelagic and benthic processes. For shallow waters, close coupling is also anticipated from the empirical relationship between production, water depth and detrital C flux of Suess \& Müller (1980), in which input of detrital carbon $\left(D C_{\mathrm{f}}\right)$ to the sea-bed is determined by:

$$
D C_{\mathrm{f}}=5.9 \times z^{-0.616} \times P
$$

where $z$ is water column depth $(\mathrm{m})$ and $P$ is daily production ( $\mathrm{mg} \mathrm{C} \mathrm{m}{ }^{-2}$ ). With a $20 \mathrm{~m}$ water column at each site, Eq. (3) predicts that $93 \%$ of production would impact on the benthos. However, despite elevated production and standing stock in Liverpool Bay, rates of oxygen uptake were statistically identical at the 2 sites. This suggests little of the production impacted on the local benthos in Liverpool Bay. The sediment data also imply a low input of POM, and indicate that phytodetritus may only contribute a small proportion to sedimenting POM in Liverpool Bay. In spring, benthic oxygen uptake would have required a POM input of 542 and $458 \mu \mathrm{mol} \mathrm{C} \mathrm{m}^{-2} \mathrm{~h}^{-1}$ at the Irish coastal site and Liverpool Bay respectively. This would only account for 13 and $4 \%$ of daily primary production at the 2 respective sites, implying a substantial fraction of production was recycled in the water column or lost by advection. For the Irish coastal site, Gowen et al. (1999) estimated that up to $56 \%$ of daily production was grazed by copepods during the spring bloom, indicating the importance of pelagic recycling. This contrasts with Liverpool Bay, where lower copepod abundance (Department of Agriculture for Northern Ireland unpubl. data) implies lower grazing pressure, which together with the small amount of production accounted for by benthic mineralisation argues for advection of spring production from the site. Furthermore, higher pore-water $\mathrm{NH}_{4}{ }^{+}$ and $\mathrm{P}$ concentrations at the Irish coastal site (Fig. 6) suggest input of more labile POM. Finally, the sediment Si and chlorophyll data show that, relative to Liverpool Bay, input of POM to the Irish coastal sediment contained a greater proportion of phytodetritus. Silicate pore-water concentrations and efflux from this sediment were an order of magnitude greater than in Liverpool Bay (Fig. 6), despite similar inputs of POM. In May 1996, the surface sediment $(0$ to $1 \mathrm{~cm})$ at the Irish coastal station contained $57.5 \mathrm{mg}$ pigment (chlorophyll and pheopigment) $\mathrm{m}^{-2}$ compared to $9.2 \mathrm{mg}$ pigment $\mathrm{m}^{-2}$ at Liverpool Bay.

Data from the summer provide evidence for a closer linkage between pelagic and benthic processes at the Irish coastal site (Table 5) compared to Liverpool Bay. Rates of benthic mineralisation imply similar inputs of POM at each site, and that a large proportion of daily production (67 and $>100 \%$ in Liverpool Bay and at the Irish coastal station respectively) could be mineralised in the benthos. As in the spring, however, low amounts of sediment pigment, low concentrations of pore-water $\mathrm{Si}$ and a negligible efflux of Si in Liverpool Bay suggest 
that, in fact, little of the summer input of POM to the sediment in Liverpool Bay was derived from overlying production. This implies loss of phytoplankton carbon from the area by advection, and contrasts with benthic data from the Irish coastal site which indicates a greater input of phytodetritus to the sediment. Efflux of Si from the sediment at this site could support $84 \%$ of summer phytoplankton production (Table 5). Since flagellates represented a significant proportion of late summer phytoplankton biomass (Table 6), the sediment efflux of Si may have been sufficient to support the bulk of diatom production. The same argument does not hold for Liverpool Bay. The negligible efflux of Si from the sediment, high rates of daily production, and diatom-dominated biomass suggest diatom growth was supported by an allochthonous source of Si.

Overall rates of organic ammonification were greatest at the Irish coastal site for both spring and summer (Table 5). Coupled denitrification could account for $20 \%$ (spring) and 19\% (summer) of ammonified $\mathrm{N}$ at this site, with the remaining 80 and $81 \%$ being returned to the overlying water as either $\mathrm{NO}_{3}{ }^{-}$(20 or $19 \%$ ) or $\mathrm{NH}_{4}^{+}\left(60\right.$ or $61 \%$ ). In contrast, $D_{\mathrm{n}}$ represented a minor sink for $\mathrm{N}$ in Liverpool Bay (0 and 10\%), with $\mathrm{N}$ being recycled to the water column as $\mathrm{NO}_{3}{ }^{-}$(44 or $53 \%$ ) or $\mathrm{NH}_{4}{ }^{+}$(56 or $37 \%$ ). The significance of benthic $\mathrm{N}$ recycling to pelagic production can be assessed by comparing supply $\left(\mathrm{NO}_{3}{ }^{-}\right.$and $\mathrm{NH}_{4}{ }^{+}$efflux from the sediment) with demand (daily $\mathrm{N}$ production) and assuming a C:N ratio of 7:1. In Liverpool Bay, the contribution of $\mathrm{N}$ from the benthos to daily production was minimal $(\leq 6 \%)$, but reached $18 \%$ during the summer at the Irish coastal site. These estimates are low compared to other coastal environments, where $\mathrm{N}$ supply from the sediment may support between 30 and $70 \%$ of overlying production (Billen \& Lancelot 1988). The amount of $\mathrm{N}$ assimilated during daily production that was permanently lost via denitrification can also be calculated by comparing measured rates of $D_{\mathrm{n}}$ with the daily $\mathrm{N}$ requirements for production. Overall, this suggests denitrification represented a minor sink for assimilated $\mathrm{N}, \leq 8 \%$ at the Irish coastal station and $\leq 1 \%$ in Liverpool Bay.

Dividing the oxygen uptake rates by the total efflux of $\mathrm{NO}_{3}{ }^{-}, \mathrm{NH}_{4}{ }^{+}$and $\mathrm{N}_{2}$ gives a measure of the sedimentary mineralisation ratios for $\mathrm{C}$ and $\mathrm{N}$. Comparing the mineralisation $\mathrm{C}: \mathrm{N}$ ratio with that for daily production suggests the organic material impacting on the benthos was impoverished in relation to N. For example, at the Irish coastal site in spring, the mineralisation C:N ratio was 19:1 compared to a production ratio of 7:1. On all other occasions and at both sites, the ratio was always $>50: 1$. This in turn suggests that whereas a proportion of production, in terms of $\mathrm{C}$, eventually impacts on the benthos, the $\mathrm{N}$ associated with production was
Table 7. Estimates of copepod and ciliate N excretion ( $\mu \mathrm{mol}$ $\mathrm{N} \mathrm{m}^{-2} \mathrm{~h}^{-1}$ ) in Irish coastal waters and Liverpool Bay during summer 1997

\begin{tabular}{|lcccc|}
\hline Month & \multicolumn{2}{c}{$\begin{array}{c}\text { Irish coastal station } \\
\text { Copepods }\end{array}$} & Ciliates & \multicolumn{2}{c|}{$\begin{array}{c}\text { Liverpool Bay } \\
\text { Copepods }\end{array}$} & Ciliates \\
\hline June & 53.8 & 114.4 & 29.3 & 620.4 \\
July & 19.8 & 391.6 & 67.7 & 206.8 \\
August & 12.7 & 136.4 & 39.3 & 211.2 \\
& & & & \\
\hline
\end{tabular}

largely recycled in the water column. Simple estimates of excretion by copepods and ciliates support this view. Assuming excretion rates of $6.07 \times 10^{-4} \mu \mathrm{mol} \mathrm{N}$ cope$\operatorname{pod}^{-1} \mathrm{~h}^{-1}$ (Holligen et al. 1984) and $2.2 \times 10^{-6} \mu \mathrm{mol} \mathrm{N}$ ciliate $^{-1} \mathrm{~h}^{-1}$ (Gast \& Horstmann 1983) recycling in the water column at the 2 coastal site can be estimated (Table 7). Heterotrophic microflagellates and dinoflagellates excretion was not considered because of poor quantification, although their contribution to recycling in the water column is acknowledged (see for example Goldman et al. 1985). Despite this limitation, it is evident that compared to sediment efflux, water-column recycled $\mathrm{N}$ was the more important source of $\mathrm{N}$ for summer growth of phytoplankton at the 2 sites.

Acknowledgements. The support of colleagues, in particular A. Reeve, P. Elliott and S. Bloomfield during research cruises and in the laboratory is gratefully acknowledged. We thank the Captains, officers and crews of the RVs 'Lough Foyle' and 'Cirolana' for their assistance. Aspects of the work presented here formed part of the UK JoNuS (Joint Nutrient Programme) for which the financial support of the UK Department of Environment Transport and Regions, Department of Agriculture (NI) and Ministry of Agriculture Fisheries and Food is acknowledged.

\section{LITERATURE CITED}

Abdullah MI, Royle LR (1973) Chemical evidence for the dispersal of River Mersey run-off in Liverpool Bay. Estuar Coast Mar Sci 1:401-409

Billen G, Lancelot C (1988) Modelling benthic nitrogen cycling in temperate coastal ecosystems. In Blackburn TH, Sørensen J (eds) Nitrogen cycling in coastal marine environments (Scope Report No. 33). Wiley, New York, p 341-378

Brzezinski MA (1985) The Si:N ratio of marine diatoms: interspecific variability and the effect of some environmental variables. J Phycol 21:347-357

Cadée GC (1990) Increased bloom. Nature 346:418

Cadée GC, Hedgeman J (1986) Seasonal and annual variation in Phaeocystic pouchetii (Haptophyceae) in the westernmost inlet of the Wadden Sea during the 1973 to 1985 period. Neth J Sea Res 20:29-36

de Jonge VN, Bakker JF, van Stralen M (1996) Recent changes in the contributions of River Rhine and North Sea to the eutrophication of the western Dutch Wadden Sea. Neth J Aquat Ecol 30:27-39 
Dodge JD (1982) Marine dinoflagellates of the British Isles. Her Majesty's Stationery Offices, London

Egge JK, Aksnes DL (1992) Silicate as regulating nutrient for phytoplankton competition. Mar Ecol Prog Ser 83:281-289

Ewins PA, Spencer CP (1967) The annual cycle of nutrients in the Menai Straits. J Mar Biol Assoc UK 47:533-542

Foster P (1984) Nutrient distributions in the winter regime of the northern Irish Sea. Mar Environ Res 13:81-95

Foster P, Hunt DTE, Pugh KB, Foster GM, Savidge G (1977) A seasonal study of the distribution of surface state variables in Liverpool Bay. I. Winter data. J Exp Mar Biol Ecol 29: 303-313

Foster P, Voltolana D, Beardall J (1982) A seasonal study of the distribution of surface state variables in Liverpool Bay. IV. The spring bloom. J Exp Mar Biol Ecol 62:93-115

Gast V, Horstmann U (1983) N-remineralisation of phyto- and bacterioplankton by the marine ciliate Euplotes vannus. Mar Ecol Prog Ser 13:55-60

Gibson CE, Stewart BM, Gowen RJ (1997) A synoptic study of nutrients in the north-west Irish Sea. Estuar Coast Shelf Sci 45:27-38

Gieskes WWC, Kraay GW (1975) The phytoplankton spring bloom in Dutch coastal waters of the North Sea. Neth J Sea Res 9:166-196

Gillooly M, O'Sullivan G, Kirkwood D, Aminot A (1992) The establishment of a database for trend monitoring of nutrients in the Irish Sea. Fisheries Research Centre, Dublin (EC Norsap Contract Report No: B6618-89-03)

Goldman JC, Caron DA, Anderson OK, Dennett MR (1985) Nutrient cycling in a microflagellate food chain. I. Nitrogen dynamics. Mar Ecol Prog Ser 24:231-242

Gowen RJ, Bloomfield SP (1996) Chlorophyll standing crop and phytoplankton production in the western Irish Sea during 1992 and 1993. J Plankton Res 18:1753-1751

Gowen RJ, Stewart BM, Mills DK, Elliot P (1995) Regional differences in stratification and its effect on phytoplankton production and biomass in the northwestern Irish Sea. J Plankton Res 17:753-769

Gowen RJ, McCullough G, Kleppel GS, Houchin L, Elliott P (1999) Are copepods important grazers of the spring bloom in the western Irish Sea? J Plankton Res 21: $465-483$

Hargrave BT (1973) Coupling carbon flow through some pelagic and benthic communities. J Fish Res Board Can 30: 1317-1326

Hargrave BT, Philips GA (1989) Decay times of organic carbon in sedimented detritus in a macrotidal estuary. Mar Ecol Prog Ser 56:271-279

Hasle GR, Syvertsen EE (1996) Marine diatoms. In: Tomas CR (ed) Identifying marine diatoms and dinoflagellates. Academic Press Inc, San Diego, p 5-385

Hickel W, Mangelsdorf P, Berg J (1993) The human impact in the German Bight: eutrophication during three decades (1962-1991). Helgol Meeresunters 47:243-263

Holligen PM, Williams PJ LeB, Purdie D, Harris RP (1984) Photosynthesis, respiration and nitrogen supply of plankton populations in stratified, frontal and tidally mixed shelf waters. Mar Ecol Prog Ser 17:201-213

Jensen MH, Lomstein E, Sørensen J (1990) Benthic ammonium and nitrate flux following sedimentation of a spring phytoplankton bloom in Aarhus Bight, Denmark. Mar Ecol Prog Ser 61:87-96

Joint IR, Pomroy AJ (1993) Phytoplankton biomass and production in the southern North Sea. Mar Ecol Prog Ser 99: 169-182

Jones PGW, Folkard AR (1971) Hydrographic observations in the eastern Irish Sea with particular reference to the dis- tribution of nutrient salts. J Mar Biol Assoc UK 51:159-182 Jones PGW, Haq SM (1963) The distribution of Phaeocystis in the eastern Irish Sea. J Cons Perm Int Explor Mer 28:8-20

Kelly RJ, Nixon SW (1984) Experimental studies of the effect of organic deposition on the metabolism of a coastal marine bottom community. Mar Ecol Prog Ser 17:157-169

Kennington K, Allen JR, Shammon TM, Hartnoll RJ, Wither A, Jones P (1997) The distribution of phytoplankton and nutrients in the north east Irish Sea during 1996. Environment Agency, Bristol, UK (R\&D Tech Rep E30)

Kennington K, Allen JR, Shammon TM, Hartnoll RJ, Wither A, Jones P (1998) The distribution of phytoplankton and nutrients in the north east Irish Sea during 1997. Environment Agency, Bristol, UK (R\&D Tech Rep E55)

Kirkwood DS (1992) Stability of solutions of nutrient salts during storage. Mar Chem 38:151-164

Kirkwood DS (1996) Nutrients: practical notes on their determination in seawater. ICES, Copenhagen No 17

Levasseur M, Therriault JC, Legrandre L (1984) Hierarchical control of phytoplankton succession by physical factors. Mar Ecol Prog Ser 19:211-222

Lohse L (1994) Sediment-water exchange of nitrogen compounds and oxygen in the North Sea. PhD thesis. University of Groningen, Groningen

Nedwell DB (1987) Distribution and pool sizes of microbially available carbon in sediment measured by a microbiological assay. FEMS Microbiol Ecol 45:47-52

Nedwell DB, Trimmer M (1996) Nitrogen fluxes through the upper estuary of the Great Ouse, England: the role of the bottom sediments. Mar Ecol Prog Ser 142:273-286

Nielsen LP (1992) Denitrification in sediment determined from nitrogen isotope pairing. Fedn Eur Microbiol Soc (FEMS) Microbiol Ecol 86:357-362

Nielsen LP, Glud RN (1996) Denitrification in a coastal sediment measured in situ by the nitrogen isotope pairing technique applied to a benthic flux chamber. Mar Ecol Prog Ser 137:181-186

Nixon SW (1981) Remineralisation and nutrient recycling in coastal marine ecosystems. In: Neilson BJ, Cronin LE (eds) Estuaries and nutrients. Humana Press, Clifton, NJ, p 111-138

Officer CB, Ryther JH (1980) The possible importance of silicon in marine eutrophication. Mar Ecol Prog Ser 3:83-91

Oviatt CA, Keller AA, Sampou PA, Beatty LL (1986) Patterns of productivity during eutrophication: a mesocosm experiment. Mar Ecol Prog Ser 28:69-80

Parsons TR, Takahashi M, Hargrave B (1984) Biological oceanographic processes, 2nd edn. Pergamon Press, Oxford

Peperzak L, Colijn F, Gieskes WWC, Peeters JCH (1998) Development of the diatom-Phaeocystis spring bloom in the Dutch coastal zone of the North Sea: the silicate depletion versus the daily irradiance threshold hypothesis J Plankton Res 20:517-537

Radach G, Berg J, Hagmeier E (1990) Long-term changes in the annual cycles of meteorological, hydrographic, nutrient and phytoplankton time series at Helgoland and at LV ELBE 1 in the German Bight. Cont Shelf Res 19:305-328

Redfield AC (1958) The biological control of chemical factors in the environment. Am Sci 46:205-221

Riegman R, Noordeloos AAM, Cadée GC (1992) Phaeocystis blooms and eutrophication of the continental coastal zone of the North Sea. Mar Biol 112:479-484

Riegman R, Kuipers BR, Noordeloos AAM, Witte HJ (1993) Size differential control of phytoplankton and the structure of plankton communities. Neth J Sea Res 31:255-265

Riley GA (1957) Phytoplankton of the North Central Sargasso Sea, 1950-52. Limnol Oceanogr 2:252-270 
Rosenberg R, Elmgren R, Fleischer S, Jonsson P, Persson G, Dahlin H (1990) Marine eutrophication case studies in Sweden. Ambio 19:102-108

Rysgaard S, Christensen PB, Nielsen LP (1995) Seasonal variation in nitrification and denitrification in estuarine sediment colonised by benthic microalgae and bioturbating infauna. Mar Ecol Prog Ser 126:111-121

Schaub BEM, Gieskes WWC (1991) Eutrophication of the North Sea: the relation between Rhine river discharge and chlorophyll a concentration in Dutch coastal waters. In: Elliott M, Ducrotoy JP (eds) Estuaries and coasts: spatial and temporal intercomparisons. Olsen \& Olsen, Fredeborg, p 85-90

Sivyer DB (1999) Nitrogen cycling in intertidal sediments of the Wash, UK. MSc thesis, School of Environmental Sciences, University of East Anglia, Norwich

Sloth NP, Blackburn TH, Hansen LS, Risgaard-Petersen N, Lomstein BA (1995) Nitrogen cycling in sediments with different organic loading. Mar Ecol Prog Ser 116:163-170

Smayda TJ (1990) Novel and nuisance phytoplankton blooms in the sea: evidence for a global epidemic. In: Graneli E, Sundström B, Edler L, Anderson D (eds) Toxic marine phytoplankton. Elsevier Science Publishing Co Inc, Amsterdam, p 29-40

Spencer CP (1972) Plant nutrient and productivity study. In: Out of sight out of mind, Vol 2, Her Majesty's Stationery Offices, London, p 357-415

Steidinger KA, Tangen K (1996) Dinoflagellates. In: Tomas CR (ed) Identifying marine diatoms and dinoflagellates. Academic Press Inc, San Diego, p 387-584

Strathman RR (1967) Estimating the organic carbon content of phytoplankton from cell volume or plasma volume. Limnol Oceanogr 12:411-418

Strickland JDH, Parsons TR (1968) A practical handbook of seawater analysis. Bull Fish Res Board Can 16:1-311

Suess E, Müller PJ (1980) Productivity, sedimentation rate

Editorial responsibility: Joseph Pawlik (Contributing Editor), Wilmington, North Carolina, USA and sedimentary organic matter in the oceans. II. Elemental fractionation. Colloques Int Cent Natn Rech Sci 293: $17-26$

Tett P (1973) The use of log normal statistics to describe the phytoplankton populations from the Firth of Lorne area. J Exp Mar Biol Ecol 11:126-136

Tett P (1987) Plankton. In: Baker JM, Wolff WM (eds) Biological surveys of estuaries and coasts. Cambridge University Press, Cambridge, p 280-341

Tett P, Gowen RJ, Grantham B, Jones K, Miller BS (1986) The phytoplankton ecology of the Firth of Clyde sea-lochs Striven and Fyne. Proc R Soc Edinb (Sect B) 90:223-238

Trimmer M, Gowen RJ, Stewart BM, Nedwell DB (1999) The spring bloom and its impact on benthic mineralisation rates in western Irish Sea sediments. Mar Ecol Prog Ser 185:37-46

Trimmer M, Nedwell DB, Sivyer D, Malcolm SJ (2000) Seasonal benthic organic matter mineralisation measured by oxygen uptake and denitrification along a transect of the inner and outer River Thames estuary, UK. Mar Ecol Prog Ser 197:103-119

Upton AC, Nedwell DB, Parkes RJ, Harvey SM (1993) Seasonal benthic microbial activity in the southern North Sea; oxygen uptake and sulphate reduction. Mar Ecol Prog Ser 101:273-281

van Bennekom AJ, Gieskes WWC, Tijssen SB (1975) Eutrophication of Dutch coastal waters. Proc R Soc Lond B 189: 359-374

van Raaphorst W, Kloosterhuis HT, Berghuis EM, Gieles AJM, Malschaert JFP, van Noort GJ (1992) Nitrogen cycling in two types of sediments of the southern North Sea (Frisian Front, Broad Fourteens): field data and mesocosm results. Neth J Sea Res 28:293-316

Woods BJB, Tett PB, Edwards A (1973) An introduction to the phytoplankton, primary production and relevant hydrography of Loch Etive. J Ecol 61:569-585

Submitted: January 24, 2000; Accepted: June 20, 2000 Proofs received from author(s): November 13, 2000 